\title{
Erratum to: The contested nature of coastal climate change-commentary to Niven and Bardsley. Planned retreat as a management response to coastal risk: a case study from the Fleurieu Peninsula, South Australia
}

\author{
Ralf Buckley
}

Published online: 11 December 2013

(c) Springer-Verlag Berlin Heidelberg 2013

Erratum to: Reg Environ Change (2013) 13:211-214

DOI 10.1007/s10113-012-0383-5

This Erratum is issued to correct a typographical error in references to the work of Professor Bent Flyvbjerg, under which the letter ' $\mathrm{j}$ ' was inadvertently omitted from the spelling of the surname. The correct text and references are as follows.

The fifth sentence in the first paragraph of the "Introduction" section should read as:

The politicization of scientific information is well known in some fields, such as disease, defence and development (Flyvbjerg et al. 2012).

The fourth sentence in the first paragraph of the section headed "Information Sources" should read as:

Just as industry proponents work to create a dominant media myth in support of the development proposals (Flyvbjerg et al. 2002); however, BSC has worked to create a media myth in support of its current coastal retreat policy.

The relevant citations in the References section should read as:

The online version of the original article can be found under doi:10. 1007/s10113-012-0383-5.

R. Buckley $(\bowtie)$

School of Environment, Griffith University,

Gold Coast, QLD 4222, Australia

e-mail: r.buckley@griffith.edu.au

\section{References}

Flyvbjerg B, Holm MS, Buhl S (2002) Underestimating costs in public works projects: error or lie? J Am Plan Assoc 68:279-295

Flyvbjerg B, Landman T, Schram S (2012) Real social science. Cambridge UP, Cambridge 